\title{
Arsenic remediation by formation of arsenic sulfide minerals in a continuous anaerobic bioreactor
}

\author{
Lucia Rodriguez-Freire $^{\mathrm{a}, \#}$, Sarah E. Moore ${ }^{\mathrm{a}}$, Reyes Sierra-Alvarez ${ }^{\mathrm{a}}$, Robert A. Root ${ }^{\mathrm{b}}$, Jon \\ Chorover $^{\mathrm{b}}$, and James A. Field ${ }^{\mathrm{a}}$ \\ aDepartment of Chemical and Environmental Engineering, The University of Arizona P.O. Box \\ 210011, Tucson, Arizona, USA \\ ${ }^{b}$ Department of Soil, Water and Environmental Science, The University of Arizona P.O. Box \\ 210038, Tucson, Arizona, USA
}

\section{Abstract}

Arsenic (As) is a highly toxic metalloid that has been identified at high concentrations in groundwater in certain locations around the world. Concurrent microbial reduction of arsenate $\left(\mathrm{As}^{\mathrm{V}}\right)$ and sulfate $\left(\mathrm{SO}_{4}{ }^{2-}\right)$ can result in the formation of poorly soluble arsenic sulfide minerals (ASM). The objective of this research was to study As biomineralization in a minimal iron environment for the bioremediation of As-contaminated groundwater using simultaneous $\mathrm{As}^{\mathrm{V}}$ and $\mathrm{SO}_{4}{ }^{2-}$ reduction. A continuous-flow anaerobic bioreactor was maintained at slightly acidic $\mathrm{pH}$ (6.25-6.50) and fed with $\mathrm{As}^{\mathrm{V}}$ and $\mathrm{SO}_{4}{ }^{2-}$, utilizing ethanol as an electron donor for over $250 \mathrm{~d}$. A second bioreactor running under the same conditions but lacking $\mathrm{SO}_{4}{ }^{2-}$ was operated as a control to study the fate of As (without $\mathrm{S}$ ). The reactor fed with $\mathrm{SO}_{4}{ }^{2-}$ removed an average $91.2 \%$ of the total soluble As at volumetric rates up to $2.9 \mathrm{mg} \mathrm{As} /(\mathrm{L} \cdot \mathrm{h})$, while less than $5 \%$ removal was observed in the control bioreactor. Soluble $\mathrm{S}$ removal occurred with an $\mathrm{S}$ to As molar ratio of 1.2, suggesting the formation of a mixture of orpiment- $\left(\mathrm{As}_{2} \mathrm{~S}_{3}\right)$ and realgar-like (AsS) solid phases. Solid phase characterization using K-edge X-Ray absorption spectroscopy confirmed the formation of a mixture of $\mathrm{As}_{2} \mathrm{~S}_{3}$ and AsS. These results indicate that a bioremediation process relying on the addition of a simple, low-cost electron donor offers potential to promote the removal of As from groundwater with naturally occurring or added sulfate by precipitation of ASM.

\section{Keywords}

Arsenate reduction; sulfate reduction; orpiment; realgar; biomineralization; bioremediation

\section{Introduction}

Arsenic (As) is a highly toxic, ubiquitous metalloid found globally in groundwater. The maximum As concentration considered safe in drinking water by the World Health Organization (WHO, 1993) and the US Environmental Protection Agency (US-EPA, 2001)

\footnotetext{
\#Corresponding author: Department of Chemical and Environmental Engineering, University of Arizona, P.O. Box 210011, Tucson, Arizona, Tel. 520-621-2591, Fax. 520-621-6048, luciar@email.arizona.edu.
} 
is $10 \mu \mathrm{g} / \mathrm{L}$ Exposure to As in drinking water poses a risk to hundreds of millions of people around the world (Murcott, 2012). High As concentrations in groundwater are often related with As-bearing parent rock materials which, either by natural or anthropogenic causes, become mobilized (Smedley and Kinniburgh, 2002). Due to its chalcophile nature, As is commonly present in sulfide rock deposits as part of As-sulfide minerals (ASM). The most common ASMs are orpiment $\left(\mathrm{As}_{2} \mathrm{~S}_{3}\right)$, realgar (AsS) and arsenopyrite (FeAsS), which are found in association with some valuable metals, such as gold, silver and copper (Williams, 2001). Mining operations that extract the ore from these rock deposits will produce acid rock drainage (ARD) which is characterized by high acidity and elevated levels of sulfate $\left(\mathrm{SO}_{4}{ }^{2-}\right)$, As, iron (Fe) and other toxic metals (Hayes et al., 2014). ARD can be treated by promoting the biological reduction of $\mathrm{SO}_{4}{ }^{2-}$ to sulfide $\left(\mathrm{H}_{2} \mathrm{~S}\right)$, which will result in precipitation of low solubility metal sulfides (Kaksonen and Puhakka, 2007). Similarly, As could be removed by stimulating the microbial reduction of $\mathrm{SO}_{4}{ }^{2-}$ and $\mathrm{ASM}$ precipitation.

The interrelationship between the biogeochemical cycles of As and sulfur (S) can be harnessed to promote the precipitation of ASM. Biological precipitation has been proven to be the source o ASM deposits in the environment. The ratio ${ }^{34} \mathrm{~S} /{ }^{32} \mathrm{~S}$ of biologically formed ASM has been shown to correspond with the ratio of ASM in Andean sediments (Demergasso et al., 2007). Root et al., (2013) found evidence of realgar precipitation under sulfidic conditions in simulated landfill column experiments. The role of ASM as a sink for As is complicated by the presence of Fe. Most laboratory-scale bioreactors and microcosms studies have focused on studying the formation of iron-bearing ASM that result when Fe is also present in the system (Altun et al., 2014). However, the formation of ASM in systems with low $\mathrm{Fe}$ concentrations will be relevant in $\mathrm{SO}_{4}{ }^{2-}$ rich waters, since $\mathrm{Fe}-\mathrm{S}$ minerals are less soluble than ASM (O'Day et al., 2004). Battaglia-Brunet et al., (2012) studied the precipitation of ASM in a Fe-free bioreactor under acidic conditions ( $\mathrm{pH} 5$ ). Since the solubility of ASM is low under acidic conditions and increases drastically around $\mathrm{pH} 7$ due to the formation of thioarsenite species (Wilkin et al., 2003), it is necessary to understand the process of ASM formation in the near neutral $\mathrm{pH}$ range.

The oxidized species of As, arsenate $\left(\mathrm{As}^{\mathrm{V}}, \mathrm{H}_{2} \mathrm{AsO}_{4}{ }^{-}\right.$and $\mathrm{HAsO}_{4}{ }^{2-}$, in circumneutral $\mathrm{pH}$ ), and $\mathrm{S}\left(\mathrm{SO}_{4}{ }^{2-}\right)$ will be microbially reduced to arsenite $\left(\mathrm{As}^{\mathrm{III}}, \mathrm{H}_{3} \mathrm{AsO}_{3}\right)$ and $\mathrm{H}_{2} \mathrm{~S}$, respectively, under reducing conditions and in the presence of an electron donor (e-donor) that supports the microbial reduction processes (van Lis et al., 2013). Ethanol is a commonly used e-donor in $\mathrm{SO}_{4}{ }^{2-}$-reducing operations due to its low cost and availability (Kaksonen et al., 2003). Once in the reduced state, $\mathrm{As}^{\mathrm{III}}$ and $\mathrm{H}_{2} \mathrm{~S}$ could form an ASM. In this regard it is important to note that previous batch studies, including a recent investigation from our research group have demonstrated that the $\mathrm{pH}$ value has a dramatic effect on the extent and rate of ASM formation by anaerobic microorganisms, as well as the stoichiometric composition of the precipitate. Rodriguez-Freire et al., (2014). Batch experiments used to study the reduction of $\mathrm{SO}_{4}{ }^{2}$ - and $\mathrm{As}^{\mathrm{V}}$ by an anaerobic mixed culture at different $\mathrm{pH}$ values $(6.1-7.2)$ showed that ASM formation is greatly enhanced at mildly acidic $\mathrm{pH}$ conditions. Furthermore, the proportion of orpiment in the ASM increases with $\mathrm{pH}$.

Therefore, this study was undertaken to investigate whether effective biological removal of As through As-sulfide precipitation under mildly acidic $\mathrm{pH}$ conditions (6.25-6.50) could be 
maintained in a continuous flow bioreactor operated for an extended time period in order to assess the potential of the process for As remediation. The study also carried out to gain more insight on the mechanisms of ASM formation. An anaerobic bioreactor was used to promote the reduction of $\mathrm{SO}_{4}{ }^{2-}$ and $\mathrm{As}^{\mathrm{V}}$, using ethanol as the electron donor in a minimal $\mathrm{Fe}$ environment. A second bioreactor without $\mathrm{SO}_{4}{ }^{2-}$ addition was run in parallel as a control to ascertain the role of $\mathrm{S}$ in the immobilization of As. The performance of the reactors was evaluated by the speciation of As and $\mathrm{S}$ in the liquid medium, while the solid phase was characterized by spectroscopic methods.

\section{Materials and Methods}

\section{Anaerobic inoculum and mineral medium}

The bioreactors were inoculated with an anaerobic granular biofilm obtained from a fullscale bioreactor treating beer brewery wastewater (Mahou, Guadalajara, Spain). The volatile suspended solids (VSS) content of the sludge was $0.042 \pm 0.002 \mathrm{~g} \mathrm{VSS} / \mathrm{g}$ wet wt. The composition of the mineral medium used is described elsewhere (Rodriguez-Freire et al., 2014). The medium was flushed with $\mathrm{N}_{2} / \mathrm{CO}_{2}$ (80:20) to ensure anaerobic conditions. The $\mathrm{NaHCO}_{3}: \mathrm{CO}_{2}$ system was used to control the reactor $\mathrm{pH}$ between 6.50 and 6.25 (1.0 or 0.5 $\mathrm{g} / \mathrm{L} \mathrm{NaHCO}_{3}$ ).

\section{Anaerobic bioreactor set-up}

Two laboratory-scale upflow bioreactors $(620 \mathrm{~mL})$ were seeded with $13.3 \mathrm{~g}$ sludge-VSS/L and operated in parallel (Fig. S1, Supplementary Information (SI)). Reactor 1 (R1) was used

to study the $\mathrm{SO}_{4}{ }^{2-}$ reduction activity and the formation of ASM; and reactor 2 (R2) was used as the control reactor to study the methanogenic- and the $\mathrm{As}^{\mathrm{V}}$ reduction activity. The reactors were operated at a $\mathrm{HRT}$ of $24 \mathrm{~h}$ at $30^{\circ} \mathrm{C}$. Three periods of operation can be distinguished: Stage I was intended to study the sulfate reduction activity (R1) and the methanogenic activity (R2) of the inoculum using ethanol as e-donor at $\mathrm{pH}$ 6.5. Ethanol (1.5 $\mathrm{mM})$ was added to the medium in both reactors; and $\mathrm{SO}_{4}{ }^{2-}\left(1 \mathrm{mM}\right.$ as $\left.\mathrm{Na}_{2} \mathrm{SO}_{4}\right)$ was amended in R1. During Stage II and Stage III, As ${ }^{\mathrm{V}}\left(1 \mathrm{mM}\right.$ as $\left.\mathrm{Na}_{2} \mathrm{HAsO}_{4} \cdot 7 \mathrm{H}_{2} \mathrm{O}\right)$ was added to both reactors. In $\mathrm{R} 1$, the $\mathrm{SO}_{4}{ }^{2-}$ load was increased from 1.0 to $1.5 \mathrm{mM}$ to provide the stoichiometric amount required for $\mathrm{As}_{2} \mathrm{~S}_{3}$ precipitation. In both reactors the ethanol concentration was increased from 1.5 to $4.9 \mathrm{mM}$ to ensure excess of e-donor at the beginning of stage II. The average $\mathrm{pH}$ of the influent was 6.5 during stage II. In stage III, the concentration of $\mathrm{As}^{\mathrm{V}}, \mathrm{SO}_{4}{ }^{2-}$ and ethanol was maintained the same but the $\mathrm{pH}$ was decreased to 6.25. The actual values of $\mathrm{pH}$ and HRT during reactor operation are presented in the SI (Fig. S2). The operating conditions in the different stages are summarized on Table 1. pH, oxidation-reduction potential (ORP), and $\mathrm{H}_{2} \mathrm{~S}$ in influent and effluent samples were measured immediately after sampling. Samples for analysis of total dissolved $\operatorname{As}\left(\operatorname{As}_{\operatorname{Tot}}(a q)\right.$, As species, $\mathrm{SO}_{4}{ }^{2-}$, ethanol and acetate were centrifuged (10 min, 14,000 $\mathrm{xg}$ ) and stored at $-20^{\circ} \mathrm{C}$ until analysis. $\mathrm{CH}_{4}$ gas production was monitored by measuring the volume of liquid displaced in an inverted bottle containing $2 \% \mathrm{NaOH}$ (to scrub $\mathrm{CO}_{2}$ ) connected to the gas effluent. Solid samples collected periodically from the reactors for mineral characterization were homogenized, washed with deoxygenated water to remove any aqueous As, flushed 
with $\mathrm{N}_{2}$ gas and frozen at $-4^{\circ} \mathrm{C}$. At the end of stage III, the solid phase was separated by sieving. Details regarding the As mass balance in the reactors are provided in section S1.1.

\section{Analytical techniques}

A detailed description of the analytical methods is presented in the SI. Total As was measured by inductively coupled plasma-optical emission spectrometry, $\mathrm{As}^{\mathrm{V}}$ and $\mathrm{SO}_{4}{ }^{2-}$ using ion chromatography and $\mathrm{As}{ }^{\mathrm{III}}$, methylarsonic acid $\left(\mathrm{MMA}^{\mathrm{V}}\right)$ and dimethylarsonious acid $\left(\mathrm{DMA}^{\mathrm{V}}\right)$ by high pressure liquid chromatography. As ${ }^{\mathrm{III}}$ concentration was below detection in the effluent of R1 (Table S1, SI); and it corresponded with the difference between the total As and $\mathrm{As}^{\mathrm{V}}$ concentration in the effluent of R2. Therefore, the concentration of $\mathrm{As}^{\mathrm{III}}$ in the effluent of $\mathrm{R} 2$ was calculated as:

$$
\left[\mathrm{As}^{\mathrm{III}}\right]_{\text {effluent }}=\left[\mathrm{As}_{\mathrm{Tot}(\alpha q)}\right]_{\text {effluent }}-\left[\mathrm{As}^{\mathrm{V}}\right]_{\text {effluent }} \cdot \quad \text { (Eq. 1) }
$$

Dissolved sulfide $\left(\Sigma=\mathrm{H}_{2} \mathrm{~S}_{(a q)}+\mathrm{HS}^{-}+\mathrm{S}_{2}^{-}\right)$was determined colorimetrically using the methylene blue method (Truper, 1964). Hereafter dissolved sulfide is referred to as $\mathrm{H}_{2} \mathrm{~S}_{(a q)}$. Ethanol and acetate were measured by gas chromatography. Solid phase products were characterized with scanning electron microscopy with energy dispersive spectroscopy (SEM-EDS), and K-edge X-ray absorption spectroscopy (XAS), including both X-ray absorption near-edge structure (XANES) and extended X-ray absorption fine-structure (EXAFS) (Rodriguez-Freire et al., 2014). ORP, pH, and VSS were measured using standard methods (APHA, 1999).

\section{Chemical oxygen demand (COD) mass balance and loss of dissolved $\mathrm{S}$ and As}

The ratio of $\mathrm{S}$ to As loss $\left(\mathrm{S}_{\mathrm{loss}} / \mathrm{As}_{\text {loss }}\right)$ to insoluble minerals in the reactors was calculated to predict the stochiometric relation between $S$ and $A s$ in the precipitate. The $S_{\text {loss }}$ and As 1 loss $(\mathrm{mM})$ are defined as the average removal of $\Sigma \mathrm{S}_{(a q)}$ and dissolved As concentration over time in the reactor (influent $v s$. effluent), respectively, and they were calculated as follows (assuming negligible stripping of $\mathrm{H}_{2} \mathrm{~S}$ ):

$$
\begin{gathered}
\mathrm{S}_{\text {loss }}=\left(\mathrm{SO}_{4}{ }^{2-}+\mathrm{H}_{2} \mathrm{~S}_{(a q)}\right)_{\text {influent }}-\left(\mathrm{SO}_{4}{ }^{2-}+\mathrm{H}_{2} \mathrm{~S}_{(a q)}\right)_{\text {effluent }} \text { Eq. } 2 \\
\mathrm{As}_{\text {loss }}=\left(\mathrm{As}_{\text {Tot }}\right)_{\text {influent }}-\left(\mathrm{As}_{\text {Tot }}\right)_{\text {effluent }} \quad \text { Eq. } 3
\end{gathered}
$$

The COD concentration in the influent and effluent of the reactors was calculated by adding the COD of all the reduced species in the reactor streams:

$$
[\mathrm{COD}]=[\mathrm{COD}]_{\text {ethanol }}+[\mathrm{COD}]_{\text {acetate }}+[\mathrm{COD}]_{\text {methane }}+[\mathrm{COD}]_{\text {arsenite }}+[\mathrm{COD}]_{\text {sulfide }} \quad \begin{aligned}
& \text { Eq. } \\
& 4
\end{aligned}
$$

In the influent, the only COD contributor was ethanol for both reactors. The term $[\mathrm{COD}]_{\text {arsenite }}$ was zero for stage $\mathrm{I}$ in the reactors. $[\mathrm{COD}]_{\text {sulfide }}$ was zero in $\mathrm{R} 2$ since $\mathrm{SO}_{4}{ }^{2-}$ was not added. In R1, once ASM were formed and there was no measurable As ${ }^{\mathrm{III}}$ and 
$\mathrm{H}_{2} \mathrm{~S}_{(\mathrm{aq})}$ the COD was estimated by $[\mathrm{COD}]_{\text {sulfide }}=[\mathrm{COD}]_{\text {Sloss }}$ and $[\mathrm{COD}]_{\text {arsenite }}=$ $[\mathrm{COD}]_{\text {Asloss. }}$.

\section{Results}

\section{Sulfate and $A s^{V}$ reducing activity in $R 1$}

The $\mathrm{SO}_{4}{ }^{2-}$ reducing activity of the sludge was evaluated during the time course of $\mathrm{R} 1$ operation. Fig. 1 shows the reduction of $\mathrm{SO}_{4}{ }^{2-}$ and $\mathrm{H}_{2} \mathrm{~S}_{(a q)}$ production over time. Sulfate was reduced during all reactor stages, but $\mathrm{S}$ recovery as $\mathrm{H}_{2} \mathrm{~S}_{(a q)}$ was greatly affected by the introduction of As at the beginning of stage II. During stage I, $91.8 \pm 6.7 \%$ of the $\mathrm{SO}_{4}{ }^{2-}$ was removed from the influent. The concentration of $\mathrm{H}_{2} \mathrm{~S}_{(a q)}$ in the effluent corresponded to $69.1 \pm 12.5 \%$ of the total $\mathrm{SO}_{4}{ }^{2-}$ removed. The average $\mathrm{S}_{\text {loss }}$ during stage I accounted for $0.25 \pm 0.12 \mathrm{mM}$. The presence of metals, low levels of dissolved oxygen and very low $\mathrm{H}_{2} \mathrm{~S}\left({ }_{\mathrm{aq}}\right)$ stripping could explain the small $\mathrm{S}_{\text {loss }}$ during stage I (section S2.2 in SI).

At the start of stage II, $\mathrm{As}^{\mathrm{V}}$ was fed into $\mathrm{R} 1$ and the concentration of $\mathrm{SO}_{4}{ }^{2-}$ was increased. Sulfate reduction reached a new steady state after $9 \mathrm{~d}$, averaging $94.3 \pm 3.4 \%$ for the rest of the experiment (Fig. 1). However, on average only $13.7 \pm 4.5 \%$ of the $\mathrm{SO}_{4}{ }^{2-}$ removed was recovered as $\mathrm{H}_{2} \mathrm{~S}(a q)$ in the effluent, as a consequence, the $\mathrm{S}_{\text {loss }}$ increased to $1.13 \pm 0.30 \mathrm{mM}$ and the total S volumetric removal rate was $1.6 \pm 0.2 \mathrm{mg} \mathrm{S} /(\mathrm{L} \cdot \mathrm{h})$ for the remainder of R1 operation. The $\mathrm{pH}$ change from 6.50 (stage II) to 6.25 (stage III) resulted in an average increase of $18.9 \%$ in the Sloss, and $11.8 \%$ in the $\mathrm{S}$ removal rate. In conclusion, the addition of $\mathrm{As}^{\mathrm{V}}$ did not affect the $\mathrm{SO}_{4}{ }^{2-}$ reduction rate but it promoted the immobilization of $\mathrm{S}$ in the reactor, which was moderately enhanced by the decrease in the $\mathrm{pH}$ from 6.50 to 6.25 .

The fate of $\mathrm{As}^{\mathrm{V}}$ followed a trend similar to that of $\mathrm{SO}_{4}{ }^{2-}$. The concentration of $\mathrm{As}^{\mathrm{V}}$ and total soluble As in the influent and effluent are shown in Fig. 1C and 1D, respectively. Arsenate was readily eliminated and total soluble As was effectively removed during the entire experiment. $\mathrm{As}^{\mathrm{V}}$ and total As removal efficiencies quickly achieved steady-state and averaged $93.2 \pm 4.3 \%$ and $91.2 \pm 8.3 \%$, respectively. Overall, the total As volumetric removal rate during stages II and III was $2.9 \pm 0.4 \mathrm{mg} \mathrm{As} /(\mathrm{L} \cdot \mathrm{h})$. Neither As ${ }^{\mathrm{III}}, \mathrm{MMA}^{\mathrm{V}}$ nor DMA ${ }^{\mathrm{V}}$ were detected (Table $\mathrm{S} 1$ in SI). The change in $\mathrm{pH}$ from stage II to III did not impact the removal of $\mathrm{As}^{\mathrm{V}}$ significantly. These results confirm the hypothesis that $\mathrm{As}$ can be immobilized over the long-term during the operation of a $\mathrm{SO}_{4}{ }^{2-}$ reducing bioreactor.

\section{Formation of ASM in R1}

$\mathrm{S}_{\text {loss }}$ in the reactor was simultaneous with As removal, indicating the formation of ASM. The precipitation of ASM was indicated by visual observation of a yellow precipitate evident $4 \mathrm{~d}$ after As introduction, which increased in volume with operation time, as shown in Fig. 2. The stoichiometric relationship between the total As and $\mathrm{S}$ losses in the reactor provides information on the minerals formed (Table 2). A molar ratio $S_{\text {loss }} / A_{\text {loss }}$ of 1.5 and 1.0 would be expected for $\mathrm{As}_{2} \mathrm{~S}_{3}$ and AsS, respectively. The actual values of this ratio over time after As addition are shown in Fig. S3, in SI. During stage II, the average $\mathrm{S}_{\text {loss }} / \mathrm{As}_{\text {loss }}$ was $1.08 \pm 0.32\left(16 \% \mathrm{As}_{2} \mathrm{~S}_{3}\right.$ and $\left.84 \% \mathrm{AsS}\right)$, but increased by $15.6 \%$ during stage III $\left(1.28 \pm 0.26,56 \% \mathrm{As}_{2} \mathrm{~S}_{3}\right.$ and $\left.44 \% \mathrm{AsS}\right)$. Overall, the average $\mathrm{S}_{\text {loss }} / \mathrm{As}_{\text {loss }}$ for stages II and III 
was $1.20 \pm 0.30$, which would correspond to a mixture of $40 \% \mathrm{As}_{2} \mathrm{~S}_{3}$ and $60 \% \mathrm{AsS}$ suggesting the precipitate is composed of a mixture of $\mathrm{As}_{2} \mathrm{~S}_{3}$ and AsS.

Solid samples from the reactor were analyzed using XAS. Two different samples, S1 and S2, were collected $60 \mathrm{~d}$ and $176 \mathrm{~d}$ after starting the addition of As. Fig. 3A shows the EXAFS spectra and Fourier transform for the two samples analyzed in the As coordinative environment. The spectrum of S1 shows an amplitude and As-S distance of $2.27 \AA$, similar to the reference mineral $\mathrm{As}_{2} \mathrm{~S}_{3}$, which has a crystallographic As-S first shell distance of 2.28 $\AA$. The amplitude of the Fourier transformed EXAFS of S2 shows more similarity with the amplitude of reference AsS, but the $2.28 \AA$ As-S distance is similar to that of the reference mineral $\mathrm{As}_{2} \mathrm{~S}_{3}$. The As-S distance is about $0.03 \AA$ shorter in realgar. Using the EXAFS linear combination fits (LCF) to reference spectra and non-linear least squares fits ( $a b$ initio shell-by-shell fits), which gives near neighbor atoms and bond distances, and the estimated stoichiometry of the atoms in the fits at the crystallographic distances, the composition of the precipitate was calculated. S1 contained (estimated error $= \pm 4 \%$ ) $65 \% \mathrm{As}_{2} \mathrm{~S}_{3}$ and $35 \%$ AsS, and S2 42\% $\mathrm{As}_{2} \mathrm{~S}_{3}$, and 58\% AsS (Table S2). Non-linear least squares fits to $3.67 \AA$ included the first three As-backscatterer paths from each $\mathrm{As}_{2} \mathrm{~S}_{3}$ and AsS reference minerals (Table S3). These XAS-derived stoichiometries fall within the observed $\mathrm{S}_{\mathrm{loss}} / \mathrm{As}_{\text {loss }}$ of 1.0 to 1.5 for realgar and orpiment respectively (Fig. S3). The longer As-As distance observed in the Fourier transform was dissimilar from $3.19 \AA$ in orpiment and $2.58 \AA$ in realgar in both samples, a result of cancelation effects of out of phase paths, likely due to the poorlycrystalline character of the ASM precipitate. Fig. 3B shows the modeled structures of the minerals. The fitting of the EXAFS spectra to reference $\mathrm{As}_{2} \mathrm{~S}_{3}$ and AsS by linear combination and shell-by-shell indicate the mineral fraction to be formed by a mixture of both. The solid phase was also analyzed using SEM-EDS confirming the major presence of As and $\mathrm{S}$ in the minerals (Section S2.3).

\section{Arsenate reducing activity in methanogenic reactor (R2)}

$\mathrm{R} 2$ was operated without $\mathrm{SO}_{4}{ }^{2-}$ addition to study the fate of As under methanogenic conditions in the bioreactor. Arsenate was readily reduced to As ${ }^{\mathrm{III}}$ but not immobilized in R2. Fig. 4 shows the time course for the concentration of $\mathrm{As}^{\mathrm{V}}$ and total As in the influent and effluent. Within $2 \mathrm{~d}, 98.5 \%$ of the $\mathrm{As}^{\mathrm{V}}$ was reduced to $\mathrm{As}^{\mathrm{III}}$. $\mathrm{MMA}^{\mathrm{V}}$ and $\mathrm{DMA}^{\mathrm{V}}$ concentrations in the effluent were below detection limits. The average reduction of $\mathrm{As}^{\mathrm{V}}$ to $\mathrm{As}^{\mathrm{III}}$ was $91.6 \pm 6.5 \%$ over the entire time of operation. The As ${ }^{\mathrm{III}}$ produced did not undergo any further alteration and exited with the effluent. During stages II and III, the average effluent concentration of $\mathrm{As}^{\mathrm{III}}$ was $0.91 \pm 0.12 \mathrm{mM}$. The data indicate that microorganisms in methanogenic sludge readily reduced $\mathrm{As}^{\mathrm{V}}$ using ethanol as the e-donor, but do not immobilize As in the solid phase. The $\mathrm{As}^{\mathrm{V}}$ reducing capacity was not affected by the $\mathrm{pH}$ change ( 6.50 to 6.25 , stage III) or by the operation time (176 d).

\section{Fate of the electron donor in the reactors}

Ethanol was added to the reactors as an exogenous e-donor source (Table 1). The fate of ethanol and the outcome of the reactions that took place depended on the reactor and the stage of the operation. Fig 5A shows that ethanol was completely degraded in R1 since day 1 of operation. Acetate accumulated in the reactor during the first month. After that time 
acetate was effectively transformed to $\mathrm{CH}_{4}$ by the methanogens until the As addition at the beginning of stage II (Fig. 5B). After As was introduced in the reactor, $\mathrm{CH}_{4}$ production decreased to $0.92 \pm 0.57 \mathrm{mmol} \mathrm{CH} / \mathrm{L}_{\text {liq }}$ over the entire time of operation, which was $74.4 \%$ less than the expected if all the ethanol was entirely transformed to $\mathrm{CH}_{4}$, and after subtracting the $e^{-}$eq that could be used to reduce $\mathrm{As}^{\mathrm{V}}\left(2 e^{-}\right.$meq $\left.\mathrm{l}^{-1}\right)$ and $\mathrm{SO}_{4}{ }^{2-}\left(12 e^{-}\right.$meq $\left.1^{-1}\right)$. Therefore, the formation of ASM seemed to have a sustained toxic effect on the acetoclastic methanogenic community. The COD concentration in the R1 effluent was $119.8 \pm 8.1 \mathrm{mg} / \mathrm{L}$, which is $84.4 \%$ of the initial COD value during stage I (Fig. 5C). Similarly, the COD balance during stages II and III was $90.4 \%$, as $417.0 \pm 54.0 \mathrm{mg}$ COD/L were entering the reactor and $417.0 \pm 54.0 \mathrm{mg} \mathrm{COD} / \mathrm{L}$ were recovered either in the effluent or as the precipitated ASM.

The operation of R2 during the stage I was used to study the methanogenic activity of the anaerobic biofilm. During stage I, an average of $1.11 \pm 0.28 \mathrm{mM}$ ethanol was fed to R2 (Fig. 5D). Initially (first $18 \mathrm{~d}$ ), a small accumulation of acetate was detected, with a maximum concentration of $0.83 \mathrm{mM}$ acetate on day 12. After this initial period, the concentration of acetate in the effluent decreased until it became negligible. During stages II and III, $1.02 \pm 0.06 \mathrm{mM} \mathrm{As}^{\mathrm{V}}$ was being reduced, producing $0.91 \pm 0.12 \mathrm{mM}$ of $\mathrm{As}{ }^{\mathrm{III}}$. The formation of $\mathrm{As}^{\mathrm{III}}$ initially caused a strong inhibition in the $\mathrm{CH}_{4}$ production and accumulation of acetate in the effluent (Fig. 5D and 5E). Immediately after the addition of $\mathrm{As}^{\mathrm{V}}$, the acetate concentration increased to $3.31 \mathrm{mM}$, and for the first $22 \mathrm{~d}$ of stage II the ethanol fed was recovered stoichiometrically as acetate. Subsequently, the acetate started to become degraded and it reached a new steady-state $82 \mathrm{~d}$ after $\mathrm{As}^{\mathrm{V}}$ addition. $\mathrm{CH}_{4}$ production started simultaneously with the acetate disappearance from the effluent on stage I (Fig. 5E), and it achieved a steady state production of $2.03 \pm 0.12 \mathrm{mmol} \mathrm{CH}_{4} / \mathrm{L}_{\mathrm{liq}}$ until As addition. The theoretical value for the ethanol added in the reactor was $1.66 \mathrm{mmol} \mathrm{CH}_{4} / \mathrm{L}_{\text {liq }}$, suggesting a contribution of endogenous substrates in the anaerobic biofilm to the $\mathrm{CH}_{4}$ production. Overall, the evidence indicates robust acetogenic and methanogenic activity of the microbial community to support ethanol conversion to $\mathrm{CH}_{4}$. Instage II, $\mathrm{CH}_{4}$ production dropped sharply to only $0.07 \mathrm{mmol} \mathrm{CH}_{4} / \mathrm{L}_{\text {liq }}$ on day 85 due to an initial As ${ }^{\mathrm{III}}$ toxicity. However, $\mathrm{CH}_{4}$ production progressively recovered over time, reaching a new steady-state production of $5.26 \pm 1.10 \mathrm{mmol} \mathrm{CH}_{4} / \mathrm{L}_{\text {liq }} 82 \mathrm{~d}$ after the addition of $\mathrm{As}{ }^{\mathrm{V}}$. The COD recovery during stage I and stages II/III was 97.2 and $91.5 \%$ (Fig. 5F). In conclusion, although the presence of As ${ }^{\text {III }}$ initially greatly lowered the methanogenic activity of the anaerobic biofilm, the data clearly suggest methanogens become tolerant to $\mathrm{As}^{\mathrm{III}}$ after a period of adaptation.

\section{Discussion}

The results obtained demonstrate that an As-containing water stream can be remediated by promoting the concurrent biological reduction of $\mathrm{As}^{\mathrm{V}}$ and $\mathrm{SO}_{4}{ }^{2-}$ through the formation of insoluble ASM. This (bio)conversion was sustained over long-term bioreactor operation at slightly acidic $\mathrm{pH}$ with ethanol supplied as e-donor. Sulfate and $\mathrm{As}{ }^{\mathrm{V}}$ were readily reduced by the anaerobic biofilm and subsequently precipitated as a mixture of AsS and $\mathrm{As}_{2} \mathrm{~S}_{3}$, resulting in more than $91 \%$ removal of soluble As. Sulfate reduction to $\mathrm{H}_{2} \mathrm{~S}_{(a q)}$ was essential to promote the formation of insoluble ASM evidenced by the control reactor in which $\mathrm{SO}_{4}{ }^{2-}$ 
was excluded from the medium and was unable to significantly remove soluble As, but just reduced $\mathrm{As}^{\mathrm{V}}$ to $\mathrm{As}{ }^{\mathrm{III}}$.

\section{Immobilization of As by ASM precipitation}

The removal rate of As during stages II and III averaged $2.9 \pm 0.4 \mathrm{mg} \mathrm{As} /(\mathrm{L} \cdot \mathrm{h})$. This rate of As removal is higher than reported in a previous study examining As in Fe-free systems with fixed-film sulfate reducing bioreactors treating an acidic ( $\mathrm{pH} 2.7$ to 5.0) effluent at a rate of 1.5-2.0 mg As/(L·h). using glycerol, and $2.5 \mathrm{mg} \mathrm{As} /(\mathrm{L} \cdot \mathrm{h})$ using $\mathrm{H}_{2}$ as e-donor (BattagliaBrunet et al., 2012). Other literature studies have focused on the interaction between the S, As and Fe cycles at circumneutral pH (e.g., Root et al., (2013)). Altun et al., (2014) studied the precipitation of ASM in the presence of Fe in fixed-bed bioreactors with ethanol as the e-donor source. Their study included control reactors lacking the addition of $\mathrm{Fe}$, however the system was poorly buffered, and the $\mathrm{pH}$ of the medium increased from 4.0 to 7.4 , limiting the removal of As to only $8 \%$. Kirk et al., (2010) also observed insignificant As removal in a semi-continuous reactor fed with $\mathrm{As}^{\mathrm{V}}$ and $\mathrm{SO}_{4}{ }^{2-}$, with acetate as e-donor at $\mathrm{pH}$ 7.3. Finally, Rodriguez-Freire et al., (2014) observed an inversely proportional relationship between the As removal rate and the $\mathrm{pH}$ (6.1 to 7.2), with As removed at $\mathrm{pH} 6.1$ being 17-fold greater than at $\mathrm{pH}$ 7.2. Collectively, the results suggest that successful removal of As by precipitation of ASM is more feasible at slightly acidic to acidic $\mathrm{pH}$ than at slightly alkaline values.

The methanogenic sludge used as inoculum in the bioreactors was able to reduce $\mathrm{SO}_{4}{ }^{2-}$ and $\mathrm{As}^{\mathrm{V}}$ individually or concomitantly with ethanol as e-donor. The coincident reduction of $\mathrm{SO}_{4}{ }^{2-}$ to $\mathrm{H}_{2} \mathrm{~S}_{(a q)}$ and $\mathrm{As}^{\mathrm{V}}$ to As ${ }^{\mathrm{III}}$ caused super-saturation of solution with respect to ASM, which then precipitated in $\mathrm{R} 1$. Sulfate and $\mathrm{As}^{\mathrm{V}}$ reduction occurred readily in $\mathrm{R} 1$ and $\mathrm{R} 2$, respectively, when added separately. After the addition of $\mathrm{As}^{\mathrm{V}}$ as a competing e-acceptor in $\mathrm{R} 1$, the $\mathrm{SO}_{4}{ }^{2-}$-reducing activity was retarded for $9 \mathrm{~d}$ (Fig. 1A). Newman et al., (1997b) hypothesized that the inhibition of $\mathrm{SO}_{4}{ }^{2-}$-reducing activity after amending $\mathrm{As}^{\mathrm{V}}$ to the treatment was due to a bioenergetic competition. The standard redox potential for the pair $\mathrm{As}^{\mathrm{V}} / \mathrm{As}{ }^{\mathrm{III}}(60 \mathrm{mV})$ is higher than that for $\mathrm{SO}_{4}{ }^{2-} / \mathrm{H}_{2} \mathrm{~S}(-220 \mathrm{mV})$ (Hoeft et al., 2004); suggesting that microorganisms will gain more energy by utilizing $\mathrm{As}^{\mathrm{V}}$ as the terminal eacceptor than $\mathrm{SO}_{4}{ }^{2-}$. If both $\mathrm{As}^{\mathrm{V}}$ and $\mathrm{SO}_{4}{ }^{2-}$ are present, microorganisms would use $\mathrm{As}{ }^{\mathrm{V}}$ under non-limiting conditions. If the substrate becomes limited, microorganisms will start using $\mathrm{SO}_{4}{ }^{2-}$ as e-acceptor (Newman et al., 1997a; Rodriguez-Freire et al., 2014). The reduction of $\mathrm{As}^{\mathrm{V}}$ before $\mathrm{SO}_{4}{ }^{2-}$ means that when $\mathrm{H}_{2} \mathrm{~S}_{(a q)}$ is produced in the presence of As, there will be excess As ${ }^{\mathrm{III}}$ available to precipitate as ASM.

Arsenate- and $\mathrm{SO}_{4}{ }^{2-}$-reducing bacteria can commonly found associated with each other in microbial communities such as in alluvial aquifers (Saunders et al., 2005), hypersaline lakes (Kulp et al., 2006) and mining sites (Valentin-Vargas et al., 2014). Occasionally, the ability of a microbe to reduce $\mathrm{As}^{\mathrm{V}}$ and $\mathrm{SO}_{4}{ }^{2-}$ is present in a single organism, like Sulfurospirillum arsenophilum MIT-13 (Ahmann et al., 1994) or Desulfomicrobium sp. str. Ben-RB and Desulfovibrio sp. str. Ben-RA (Macy et al., 2000). Among all the $\mathrm{As}^{\mathrm{V}}$ - and $\mathrm{SO}_{4}{ }^{2-}$-reducing microorganisms that have been reported only a few are able to mineralize As. These microorganisms can precipitate ASM because of the preferential use of $\mathrm{As}^{\mathrm{V}}$ over $\mathrm{SO}_{4}{ }^{2-}$ 
(Macy et al., 2000). Desulfotomaculum auropigmentum (Newman et al., 1997a), which precipitates $\mathrm{As}_{2} \mathrm{~S}_{3}$, starts reducing $\mathrm{As}^{\mathrm{V}}$ and then $\mathrm{SO}_{4}{ }^{2-}$; however, Desulfobulbus propionicus quickly reduces $\mathrm{SO}_{4}{ }^{2-}$ before reducing $\mathrm{As}^{\mathrm{V}}$, leading to the accumulation of $\mathrm{H}_{2} \mathrm{~S}_{(a q)}$ and favoring the formation of thioarsenites, and as such was found to be unable to form an ASM. Consequently, the microbial reduction of $\mathrm{As}^{\mathrm{V}}$ and $\mathrm{SO}_{4}{ }^{2-}$ can enhance or limit the formation of ASM, depending on the consortium of microbes, by controlling the rate of formation of $\mathrm{As}^{\mathrm{III}}$ and $\mathrm{H}_{2} \mathrm{~S}_{(a q)}$.

Two major constraints dictate the feasibility of the remediation of As-contaminated waters by precipitation of ASM, pH and the activity of $\mathrm{H}_{2} \mathrm{~S}_{(a q)}$. The solubility of ASM increases as the $\mathrm{pH}$ or the $\mathrm{H}_{2} \mathrm{~S}_{(a q)}$ activity increases due to the formation of soluble thioarsenite species (Wilkin et al., 2003). Rodriguez-Freire et al., (2014) studied the stability of the mineral phases $\mathrm{As}_{2} \mathrm{~S}_{3}$ and $\mathrm{AsS}$ as a function of the $\mathrm{pH}$ and the redox potential $\left(\mathrm{E}_{\mathrm{h}}\right)$, and how as the $\mathrm{pH}$ increases, the amount of $\mathrm{H}_{2} \mathrm{~S}_{(a q)}$ required for the formation of thioarsenites decreases, at any given As activity. In this study, the $\mathrm{pH}$ of the medium was maintained between 6.25 6.50, and both $\mathrm{As}^{\mathrm{V}}$ and $\mathrm{SO}_{4}{ }^{2-}$ were supplied in a molar ratio of 1:1.5 (As:S) to ensure feasibility of the process. Battaglia-Brunet et al., (2012) worked at a lower $\mathrm{pH}$ range achieving lower As removal rates than the present study. Given the low $\mathrm{pH}$, higher As removal rates would have been expected; however, acidic $\mathrm{pH}$ may have been suboptimal for the biological $\mathrm{SO}_{4}{ }^{2-}$ and $\mathrm{As}^{\mathrm{V}}$ reduction processes, or higher $\mathrm{SO}_{4}{ }^{2-}$ to $\mathrm{As}^{\mathrm{V}}$ ratio may have caused an excess of $\mathrm{H}_{2} \mathrm{~S}_{(a q)}$, promoting the formation of soluble thioarsenites even at low pH. Furthermore, Rodriguez-Freire et al., (2014) demonstrated that the rate of As removal due to ASM formation was positively correlated with decreasing $\mathrm{pH}$. Therefore, while formation of ASM by microbial reduction of $\mathrm{As}^{\mathrm{V}}$ and $\mathrm{SO}_{4}{ }^{2-}$ can be effectively used as a remediation technique, careful management of the $\mathrm{pH}$ and $\mathrm{H}_{2} \mathrm{~S}_{(a q)}$ activity is required to maximize precipitation.

\section{Precipitation of As to AsS and $\mathrm{As}_{\mathbf{2}} \mathrm{S}_{\mathbf{3}}$}

The reduction of $\mathrm{As}^{\mathrm{V}}$ and $\mathrm{SO}_{4}{ }^{2-}$ in $\mathrm{R} 1$ produced a yellow precipitate which was visible $4 \mathrm{~d}$ after As addition. Microscopic analysis showed As-S nanoparticles with a similar composition both in the surroundings and on the surface of the bacteria (Fig. S4). Newman et al., (1997a) previously reported the intra- and extra-cellular precipitation of $\mathrm{As}_{2} \mathrm{~S}_{3}$ on $D$. auropigmentum; and Lee et al., (2007) observed filamentous As-S nanotubes growing inside Shewanella sp. HN-41. The biologically precipitated ASM are formed following the microbial reduction of $\mathrm{As}^{\mathrm{V}}$ and $\mathrm{SO}_{4}{ }_{4}^{2-}$, which takes place inside of the cytoplasmic membrane (Slyemi and Bonnefoy, 2012). Therefore, close physical association between ASM and bacteria is an indication of the microbial role in the formation of the mineral, either as a template or as a mechanism of microbial respiration.

The biogenic mineral precipitated in R1 was composed of AsS and $\mathrm{As}_{2} \mathrm{~S}_{3}$. The loss ratio $\mathrm{S}_{\text {loss }} / \mathrm{As}_{\text {loss }}$ successfully predicted the composition of the precipitate over the long-term that was confirmed by XAS analysis. However, during stage II, the stoichiometric average $\mathrm{S}_{\text {loss }} / \mathrm{As}_{\text {loss }}$ did not correspond with a mixture of $70 \% \mathrm{As}_{2} \mathrm{~S}_{3}$ and $30 \%$ AsS, this could be due to the stabilization of the reactor after the addition of As. The overall ratio $\mathrm{S}_{\mathrm{loss}} / \mathrm{As}_{\mathrm{loss}}$ for stage II and III was 1.20 predicting a mixture of $40 \% \mathrm{As}_{2} \mathrm{~S}_{3}$ and $60 \% \mathrm{AsS}$, and the XAS 
analysis of the solid phase confirmed a precipitated made of $40 \% \mathrm{As}_{2} \mathrm{~S}_{3}$ and the $60 \%$ AsS. The increase in the proportion of AsS with the incubation time could be due to the maturation of the most crystalline form, AsS, confirming the results obtained by Lee et al., (2007) in which the strain Shewanella sp. HN-41 started precipitating $\mathrm{As}_{2} \mathrm{~S}_{3}$ and, as the incubation time increased, the $\mathrm{As}_{2} \mathrm{~S}_{3}$ was transformed to $\mathrm{AsS}$ and duranusite $\left(\mathrm{As}_{4} \mathrm{~S}\right)$ and, finally, to As-S nanotubes.

The co-precipitation of $\mathrm{As}_{2} \mathrm{~S}_{3}$ and AsS was previously observed in batch experiments in a pH range of 6.1 to 7.1 (Rodriguez-Freire et al., 2014). Two hypotheses are offered to explain the simultaneous precipitation of both minerals. (1) Different microorganisms promoted the formation of each mineral. Demergasso et al., (2007) noticed the formation of AsS and $\mathrm{As}_{2} \mathrm{~S}_{3}$ in laboratory experiments using enrichment cultures originating from sediment samples; solid phase analysis of the precipitate on the microbial surface corresponded more closely to $\mathrm{As}_{2} \mathrm{~S}_{3}$, and the bulk precipitate corresponded closely to AsS. Among the microorganisms reported to precipitate ASM, two pure cultures, one strain from $\gamma$ Proteobacteria (Demergasso et al., 2007) and D. auropigmentum (Newman et al., 1997a), precipitated $\mathrm{As}_{2} \mathrm{~S}_{3}$; the strain YeAs (Ledbetter et al., 2007) precipitated AsS; and Shewanella sp. str. HN-41 (Lee et al., 2007) initially precipitated $\mathrm{As}_{2} \mathrm{~S}_{3}$, AsS, $\mathrm{As}_{4} \mathrm{~S}$ and, finally, As-S nanotubes. (2) Localized chemical variations can lead to variations in the redox conditions inside the reactor. Pourbaix diagram $\left(\mathrm{E}_{\mathrm{h}}-\mathrm{pH}\right.$ diagram) presented in RodriguezFreire et al., (2014) predicted that, at the $\mathrm{pH}$ and Eh range $(-256 \pm 27 \mathrm{mV}$, measured) in the reactor, both minerals can be formed within the standard deviation of the measurements. For a fixed $\mathrm{pH}, \mathrm{AsS}$ will be the predominant phase under more reducing conditions than $\mathrm{As}_{2} \mathrm{~S}_{3}$, and for a fixed $\mathrm{E}_{\mathrm{h}}, \mathrm{As}_{2} \mathrm{~S}_{3}$ will be predominant at more acidic conditions. Since microbial activity will control the redox conditions in the reactor, the co-precipitation of $\mathrm{As}_{2} \mathrm{~S}_{3}$ and AsS can most likely be explained by a combination of processes (1) and (2).

This study defines the combination of $\mathrm{pH}$ and $\mathrm{H}_{2} \mathrm{~S}_{(a q)}$ conditions favorable for ASM formation as a remediation strategy. This information can be used to identify groundwaters with natural conditions well-suited for this remediation approach. However, if the groundwater $\mathrm{pH}$ is not naturally favorable, the remediation approach can include addition of bases, acids and/or buffers to adjust the $\mathrm{pH}$. Sulfate and electron donor additions can also be designed to achieve a desired $\mathrm{H}_{2} \mathrm{~S}_{(a q)}$ concentration at a given $\mathrm{pH}$ condition. If excess $\mathrm{H}_{2} \mathrm{~S}_{(a q)}$ were to occur, iron additions could moreover be used to lower the $\mathrm{H}_{2} \mathrm{~S}_{(a q)}$ to levels favoring ASM formation.

\section{Conclusions}

The formation of ASM can be stimulated by promoting the concurrent biological reduction of As and $\mathrm{SO} 4$ in a continuous bioreactor with a controlled $\mathrm{pH}$ ranging from 6.25 to 6.50 . An anaerobic sludge was used as inoculum and readily reduced As and SO4 with ethanol as the e-donor. High As removal rates of $2.9 \mathrm{mg}$ As /(L.h) were achieved and formation of a precipitate composed of $\mathrm{As}_{2} \mathrm{~S}_{3}$ and $\mathrm{AsS}$, as characterized by the $\mathrm{S}_{\text {loss }} / \mathrm{As}_{\text {loss }}$ ratio and EXAFS analysis, occurred; whereas, negligible As immobilization was observed in the control reactor which lacked $\mathrm{SO}_{4}{ }^{2-}$, but instead $\mathrm{As}^{\mathrm{V}}$ was reduced to As ${ }^{\mathrm{III}}$. Taken as a whole, these results confirm that As biomineralization as a sulfide mineral phase can be used as a 
remediation technique that can be sustained over long-term operation in continuous bioreactors. Further study of the stability of the biogenic minerals is important to better understand the feasibility of the process.

\section{Supplementary Material}

Refer to Web version on PubMed Central for supplementary material.

\section{Acknowledgments}

This work was funded by a grant of the National Institute of Environment and Health Sciences-supported Superfund Research Program (NIH ES-04940). Portions of this research were carried out at Stanford Synchrotron Radiation Laboratory, a National User Facility operated by Stanford University on behalf of the U.S. Department of Energy, Office of Basic Energy Sciences. Lucia Rodriguez-Freire was partly funded by a fellowship from the Arizona Water Sustainability Program.

\section{References}

Ahmann D, Roberts AL, Krumholz LR, Morel FMM. Microbe grows by reducing arsenic. Nature. 1994; 371(6500):750-750. [PubMed: 7935832]

Altun M, Sahinkaya E, Durukan I, Bektas S, Komnitsas K. Arsenic removal in a sulfidogenic fixedbed column bioreactor. J Hazard Mater. 2014; 269(0):31-37. [PubMed: 24360509]

APHA. Standard Methods for the Examination of Water and Wastewater. Washington D.C.: APHA, AWWA and WEF. Washington D.C; 1999.

Battaglia-Brunet F, Crouzet C, Burnol A, Coulon S, Morin D, Joulian C. Precipitation of arsenic sulphide from acidic water in a fixed-film bioreactor. Water Res. 2012; 46(12):3923-3933. [PubMed: 22608606]

Demergasso CS, Chong G, Escudero L, Mur JJP, Pedros-Alio C. Microbial precipitation of arsenic sulfides in Andean salt flats. Geomicrobiol J. 2007; 24(2):111-123.

Hayes SM, Root RA, Perdrial N, Maier RM, Chorover J. Surficial weathering of iron sulfide mine tailings under semi-arid climate. Geochim Cosmochim Ac. 2014; 141:240-257.

Hoeft SE, Kulp TR, Stolz JF, Hollibaugh JT, Oremland RS. Dissimilatory arsenate reduction with sulfide as electron donor: experiments with Mono Lake water and isolation of strain MLMS-1, a chemoautotrophic arsenate respirer. Appl Environ Microb. 2004; 70(5):2741-2747.

Kaksonen A, Franzmann P, Puhakka J. Performance and ethanol oxidation kinetics of a sulfatereducing fluidized-bed reactor treating acidic metal-containing wastewater. Biodegradation. 2003; 14(3):207-217. [PubMed: 12889611]

Kaksonen AH, Puhakka JA. Sulfate reduction based bioprocesses for the treatment of acid mine drainage and the recovery of metals. Eng Life Sci. 2007; 7(6):541-564.

Kirk MF, Roden EE, Crossey LJ, Brearley AJ, Spilde MN. Experimental analysis of arsenic precipitation during microbial sulfate and iron reduction in model aquifer sediment reactors. Geochim Cosmochim Ac. 2010; 74(9):2538-2555.

Kulp TR, Hoeft SE, Miller LG, Saltikov C, Murphy JN, Han S, Lanoil B, Oremland RS. Dissimilatory arsenate and sulfate reduction in sediments of two hypersaline, arsenic-rich soda lakes: Mono and Searles lakes, California. Appl Environ Microb. 2006; 72(10):6514-6526.

Ledbetter RN, Connon SA, Neal AL, Dohnalkova A, Magnuson TS. Biogenic mineral production by a novel arsenic-metabolizing thermophilic bacterium from the Alvord Basin, Oregon. Appl Environ Microb. 2007; 73(18):5928-5936.

Lee JH, Kim MG, Yoo BY, Myung NV, Maeng JS, Lee T, Dohnalkova AC, Fredrickson JK, Sadowsky MJ, Hur HG. Biogenic formation of photoactive arsenic-sulfide nanotubes by Shewanella sp strain HN-41. P Natl Acad Sci USA. 2007; 104(51):20410-20415.

Macy JM, Santini JM, Pauling BV, O'Neill AH, Sly LI. Two new arsenate/sulfate-reducing bacteria: mechanisms of arsenate reduction. Arch Microbiol. 2000; 173(1):49-57. [PubMed: 10648104] 
Murcott, S. An international sourcebook 2012. London: IWA Publishing; 2012. Arsenic contamination in the World.

Newman DK, Beveridge TJ, Morel FMM. Precipitation of arsenic trisulfide by Desulfotomaculum auripigmentum. Appl Environ Microb. 1997a; 63(5):2022-2028.

Newman DK, Kennedy EK, Coates JD, Ahmann D, Ellis DJ, Lovley DR, Morel FMM. Dissimilatory arsenate and sulfate reduction in Desulfotomaculum auripigmentum sp. nov. Arch Microbiol. 1997b; 168(5):380-388. [PubMed: 9325426]

O'Day PA, Vlassopoulos D, Root R, Rivera N. The influence of sulfur and iron on dissolved arsenic concentrations in the shallow subsurface under changing redox conditions. P Natl Acad Sci USA. 2004; 101(38):13703-13708.

Rodriguez-Freire L, Sierra-Alvarez R, Root R, Chorover J, Field JA. Biomineralization of arsenate to arsenic sulfides is greatly enhanced at mildly acidic conditions. Water Res. 2014; 66:242-253. [PubMed: 25222328]

Root RA, Fathordoobadi S, Alday F, Ela W, Chorover J. Microscale speciation of arsenic and iron in ferric-based sorbents subjected to simulated landfill conditions. Environ Sci Technol. 2013; 47(22):12992-13000. [PubMed: 24102155]

Saunders JA, Mohammad S, Korte NE, Lee MK, Fayek M, Castle D, Barnett MO. Groundwater geochemistry, microbiology, and mineralogy in two arsenic-bearing Holocene alluvial aquifers from the United States. Acs Sym Ser. 2005; 915:191-205.

Slyemi D, Bonnefoy V. How prokaryotes deal with arsenic. Env Microbiol Rep. 2012; 4(6):571-586. [PubMed: 23760928]

Smedley PL, Kinniburgh DG. A review of the source, behaviour and distribution of arsenic in natural waters. Appl Geochem. 2002; 17(5):517-568.

Truper HG. Sulphur metabolism in Thiorhodaceae .2. Stoichiometric relationship of $\mathrm{CO}_{2}$ fixation to oxidation of hydrogen sulphide and intracellular sulphur in Chromatium okenii. A Van Leeew $\mathbf{J}$ Microb Serol. 1964; 30(4):385-394.

US-EPA. 2001. National primary drinking water regulations; arsenic and clarifications to compliance and new source contaminants monitoring final. FR. Jan 22.2001 66(4):6976.

Valentin-Vargas A, Root RA, Neilson JW, Chorover J, Maier RM. Environmental factors influencing the structural dynamics of soil microbial communities during assisted phytostabilization of acidgenerating mine tailings: A mesocosm experiment. Sci Total Environ. 2014; 500:314-324. [PubMed: 25237788]

van Lis R, Nitschke W, Duval S, Schoepp-Cothenet B. Arsenics as bioenergetic substrates. Biochim Biophys Acta, Bioenerg. 2013; 1827(2):176-188.

WHO. Recommendations. Second. Vol. 1. WHO; Geneva, Switzerland: 1993. Guidelines for drinkingwater quality; p. 188

Wilkin RT, Wallschlager D, Ford RG. Speciation of arsenic in sulfidic waters. Geochem T. 2003; 4:17.

Williams M. Arsenic in mine waters: an international study. Environ Geol. 2001; 40(3):267-278. 

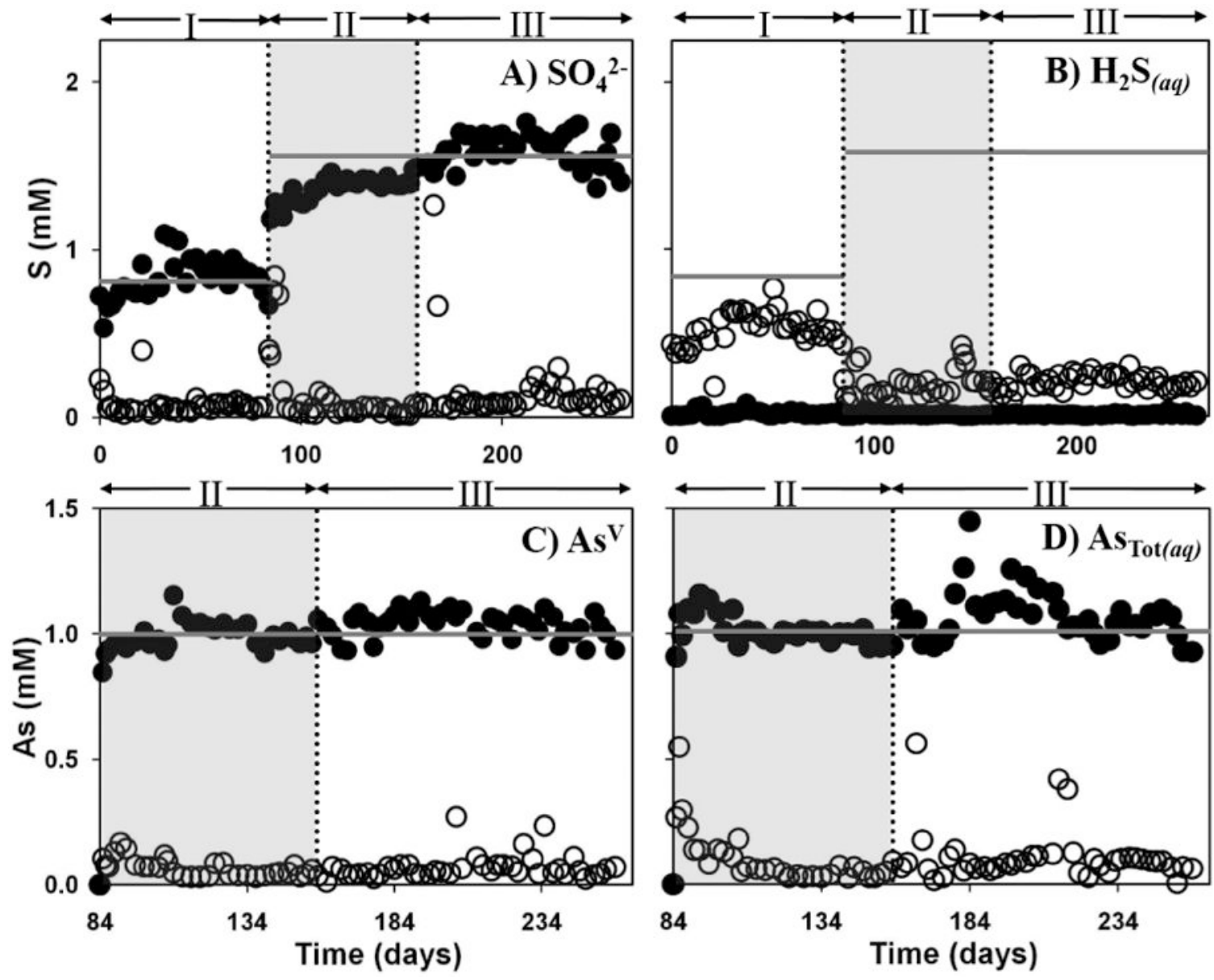

Fig. 1.

$\mathrm{S}$ and As speciation in reactor 1 in the influent $(\mathbf{O})$ and in the effluent $(\mathrm{O})$. (A) $\mathrm{SO}_{4}{ }^{2-}$ concentration; (B) DS concentration; $(\mathbf{C}) \mathrm{As}^{\mathrm{V}}$ concentration; (D) total As concentration. The vertical dashed lines indicate the separation between the three stages in the reactor. The shaded area designates the stage II of operation, right after the addition of $\mathrm{As}^{\mathrm{V}}$. The horizontal grey lines represent the theoretical concentration of the specie in the effluent if not transformation/immobilization would take place. Measured As ${ }^{\text {III }}$ concentration in the effluent was below the detectable limit (data not shown). 


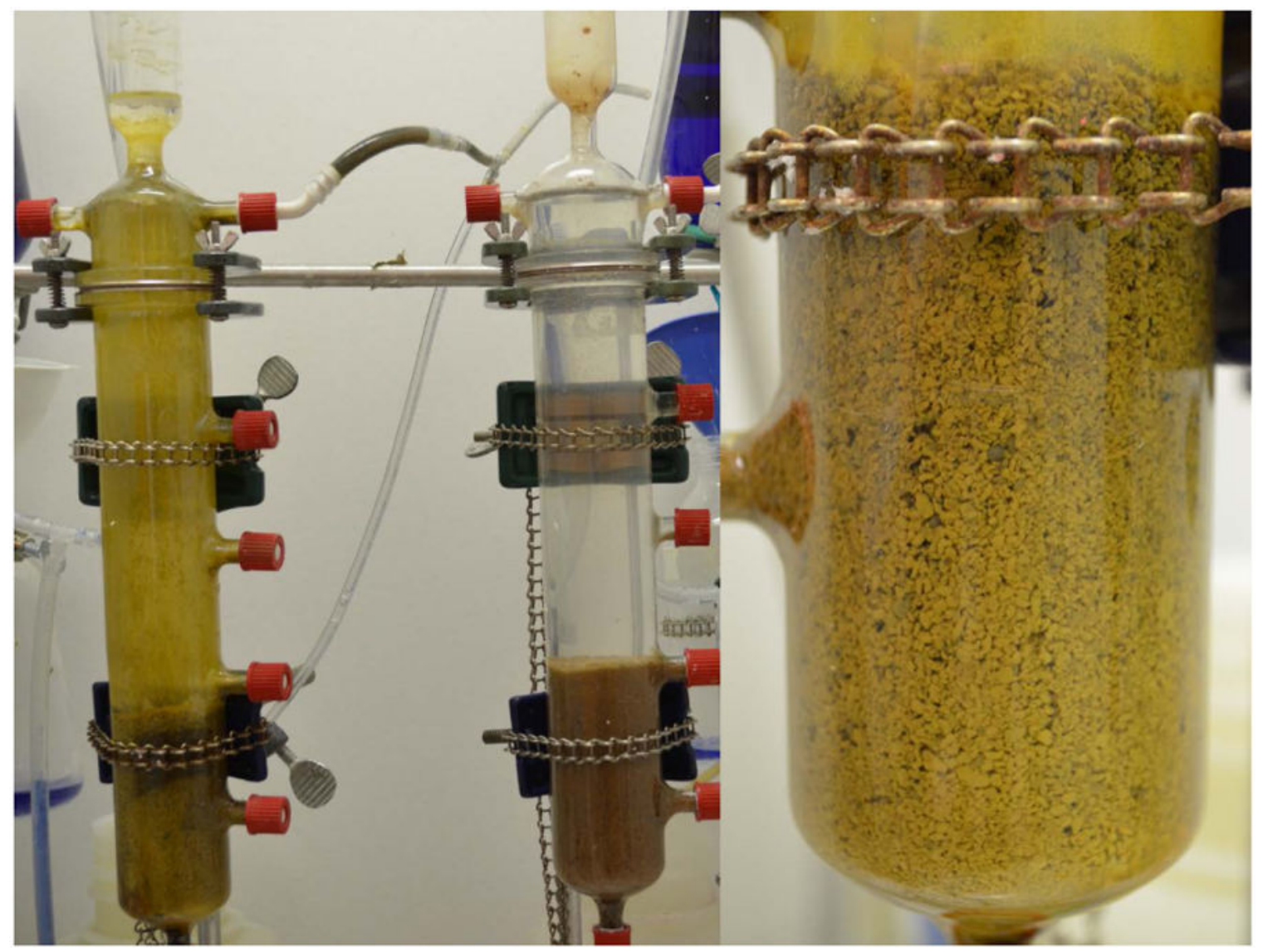

Fig. 2.

Evidence of mineral precipitation. The picture was taken $70 \mathrm{~d}$ after the addition of $\mathrm{As}^{\mathrm{V}}$. A yellow precipitate is clearly presence in R1 (left, close up in right panel), in the liquid medium and on top of the sludge. No precipitated is observed in R2 (column on right in left panel), where the medium appears clear and the sludge clean. 


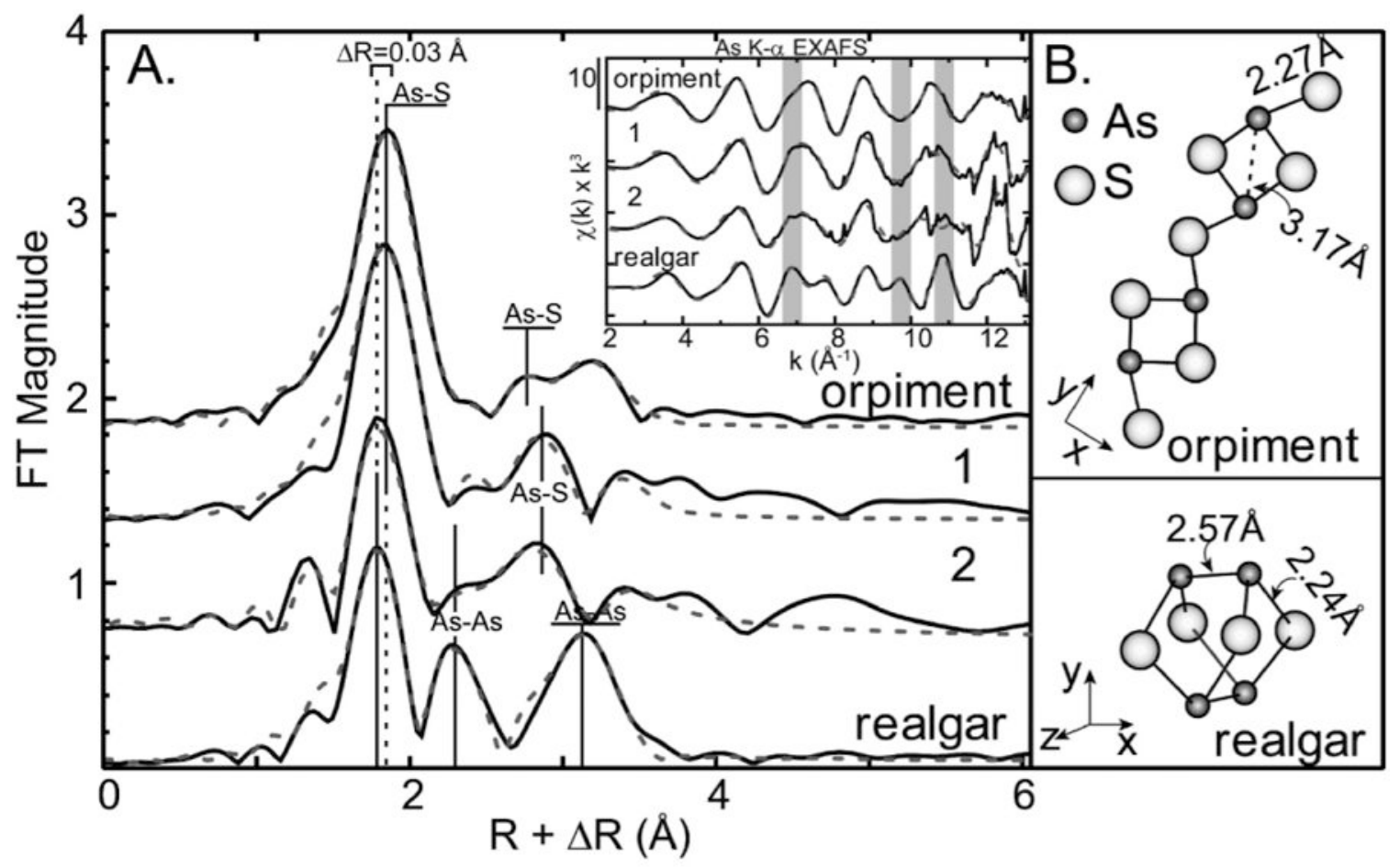

Fig. 3.

As K-a X-ray absorption spectra of the solids precipitated in the experiments $60 \mathrm{~d}$ (sample 1) and $176 \mathrm{~d}$ (sample 2). (A) The EXAFS spectra (inset window) and corresponding Fourier transforms for the experimental samples (black lines) and fits to As-S mineral and the standards (dotted lines). Vertical lines indicate As-backscatter distances and highlight differences from the references. Shaded areas in the EXAFS spectra emphasize distinct contributions from standard minerals. (B) Structure of the reference minerals showing the modeled interatomic distances. 

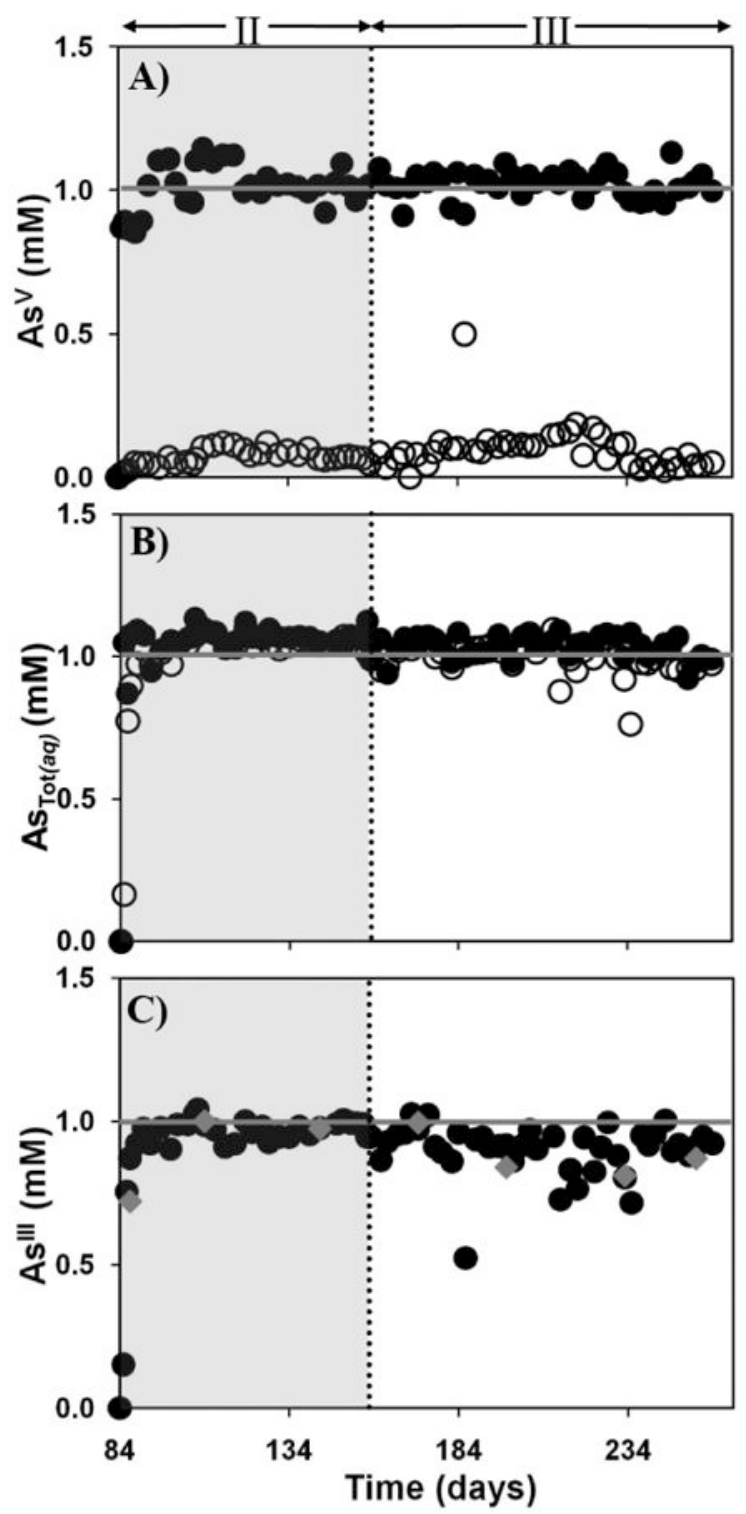

Fig. 4.

Arsenic speciation in reactor 2 influent $(\mathbf{O})$ and effluent $(\mathrm{O})$. (A) $\mathrm{As}^{\mathrm{V}}$ concentration; (B) total As concentration; $(\mathbf{C}) \mathrm{As}^{\mathrm{III}}$ concentration calculated as the difference between total As and $\mathrm{As}^{\mathrm{V}}$ concentrations in the effluent. Measured $\mathrm{As}{ }^{\mathrm{III}}$ concentrations are shown with $(\bullet)$. The vertical dashed line indicates the separation between stages II and III in the reactor. The shaded area designates the stage II of operation, right after the addition of $\mathrm{As}^{\mathrm{V}}$. The horizontal grey lines represent the theoretical concentration of each species in the effluent with no transformation/immobilization. 

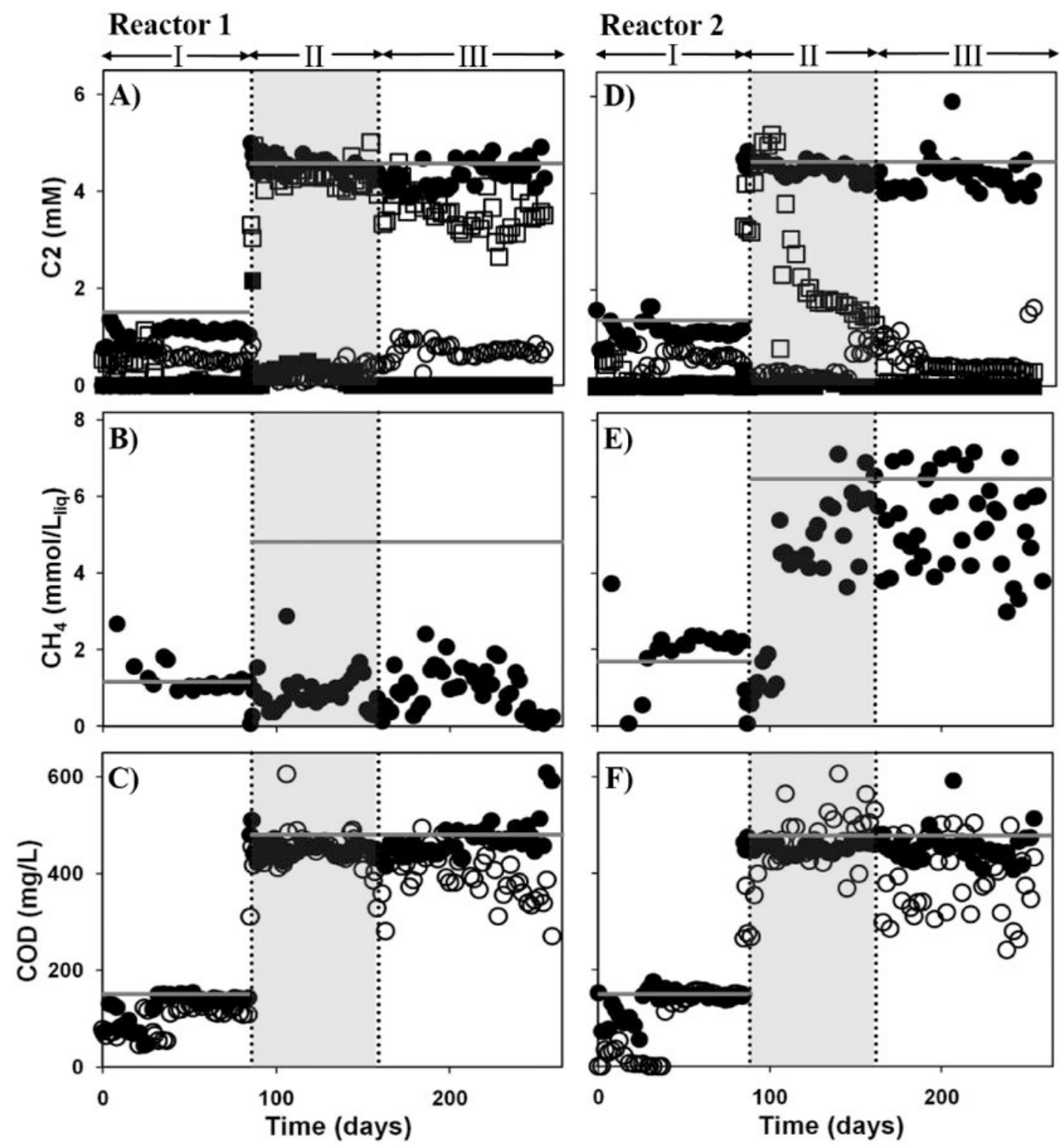

Fig. 5.

Transformation of ethanol and production of acetate and $\mathrm{CH} 4$ in the reactors. (A) ethanol and acetate concentration in $\mathrm{R} 1$; (B) production of $\mathrm{CH}_{4}$ in $\mathrm{R} 1$; (C) COD balance in $\mathrm{R} 1$; (D) ethanol and acetate concentration in $\mathrm{R} 2$; (E) production of $\mathrm{CH}_{4}$ in $\mathrm{R} 2$; (F) COD balance in R2. Ethanol in the influent $(O)$ and in the effluent $(O)$; and, acetate concentration in the influent $(\boldsymbol{\square})$ and in the effluent $(\square) . \mathrm{CH}_{4}$ production $(\boldsymbol{O})$ in the reactors. COD in the influent (O) and in the effluent $(\bigcirc)$. The vertical dashed lines indicate the separation between the three stages in the reactor. The shaded area designates the stage II of operation, right after the addition of $\mathrm{As}^{\mathrm{V}}$. The horizontal grey lines represent the theoretical concentration of the species in the effluent if no transformation/immobilization would take place. 


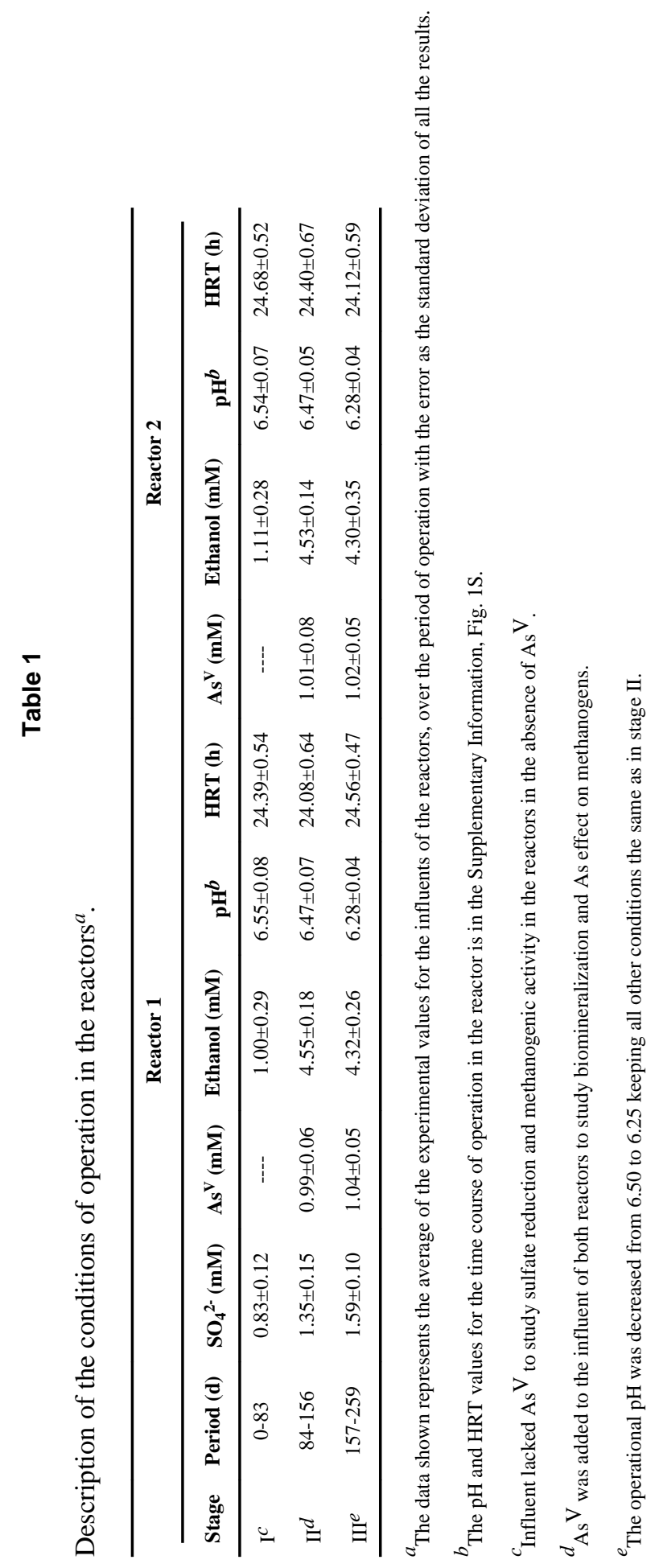


Table 2

As and $\mathrm{S}$ removal in reactor 1 and stoichiometric relationship between the $\mathrm{S}$ and As loss.

\begin{tabular}{ccccc}
\hline & $\mathbf{A s}_{\text {loss }}(\mathbf{m M})$ & $\mathbf{S}_{\text {loss }}(\mathbf{m M})$ & $\mathbf{S}_{\text {loss }} / \mathbf{A s}_{\text {loss }}$ & $\% \mathbf{A s}_{\text {removal }}$ \\
\cline { 2 - 5 } Stage I & --- & $0.23 \pm 0.12$ & --- & --- \\
Stage II & $0.94 \pm 0.11$ & $0.99 \pm 0.34$ & $1.08 \pm 0.32$ & $93.56 \pm 3.99$ \\
Stage III & $0.97 \pm 0.13$ & $1.24 \pm 0.23$ & $1.28 \pm 0.26$ & $89.86 \pm 9.82$ \\
Overall (Stages II \&III) & $0.96 \pm 0.10$ & $1.13 \pm 0.30$ & $1.20 \pm 0.30$ & $91.21 \pm 8.25$ \\
\hline
\end{tabular}

* S loss and Asloss are defined as the average removal the soluble specie ( $\mathrm{S}$ or As) concentrations over time in the reactor. 